\title{
Selected Macronutrients Uptake by Sweet Corn under Different Rates Liquid Organic Fertilizer in Closed Agriculture System
}

\author{
Zainal Muktamar ${ }^{\#}$, Fahrurrozi ${ }^{*}$, Dwatmadji ${ }^{1}$, Nanik Setyowati ${ }^{*}$, Sigit Sudjatmiko ${ }^{*}$, Muhammad Chozin ${ }^{*}$ \\ \# Soil Science Department, University of Bengkulu, Bengkulu 38371, Indonesia \\ E-mail:muktamar1959@yahoo.com \\ Agronomy Department, University of Bengkulu, Bengkulu 38371, Indonesia \\ E-mail:rozi38125@yahoo.com; nanik_srg@yahoo.com;s1g1t_s@yahoo.com;m_chozin@hotmail.com
}

${ }^{1}$ Animal Production Department, University of Bengkulu, Bengkulu 38371, Indonesia

E-mail: dwatmadji2008@yahoo.com

\begin{abstract}
In the last few years, soil deterioration due to excessive application of synthetic agrochemical has become growing concern. Use of organic fertilizer is believed to be able to enhance soil quality. The objective of this experiment was to determine nitrogen, phosphorus, and potassium uptakes by sweet corn as affected by local based liquid organic fertilizer (LOF) under closed agriculture system. The experiment was conducted in Closed Agriculture Production System (CAPS) Research Station in Air Duku Village, Bengkulu, Indonesia from March to June 2015, employing Randomized Completely Block Design with 2 factors. The first factor was 3 sweet corn genotypes, i.e. Talenta, Jambore, and Asian Honey and the second factor was 5 rates of LOF, i.e. 0, 25, 50, 75, and 100 $\mathrm{mg} \mathrm{l}^{-1}$, respectively. Each treatment combination was replicated 3 times. Foliar application of LOF was carried out every week at 2-8 weeks after planting (WAP) with total volume of $600 \mathrm{ml}$ per plant. Sweet corn leaves were sampled at the beginning of tassel emergence. The experiment revealed that sweet corn genotype significantly influenced the uptake of nitrogen, but not phosphorus and potassium. It was observed that Asian Honey genotype absorbed highest nitrogen as compared to other genotypes. In addition, increase in rates of LOF significantly raised nitrogen uptake by sweet corn, but not phosphorus and potassium.
\end{abstract}

Keywords - Liquid organic fertilizer; sweet corn; closed agriculture system

\section{INTRODUCTION}

In recent years, use of agrochemicals such as synthetic fertilizer and pesticide has increased significantly to raise crop production. Excessive application of such chemicals for a long period of time, however, will decrease soil quality as well as harm environment. Intensive use of pesticide also has negative effect on farmer's health [1],[2],[3], children health exposed to pesticides [4],[5], and female farm worker's pregnancy [6].

Uncontrolled application of synthetic fertilizer for long period of time is believed to decline soil quality. Study by [7] confirmed that long term soil fertility trial, ammoniacal nitrogen fertilizer brought about increase in exchangeable acidity accompanied with reduction of Cation Exchange Capacity (CEC), base saturation as well as exchangeable calcium $(\mathrm{Ca})$ and magnesium $(\mathrm{Mg})$. Long term application of nitrogen fertilizer also lowers soil $\mathrm{pH}$ as reported by [8]. Excessive use of nitrogen fertilizer also depletes microbial biomass carbon $(\mathrm{MBC})$ and substrate induced respiration
(SIR) [9], alters bacterial community diversity, structure, and individual taxa abundance [10]. Organic farming is believed to be an alternative solution to recover quality of degraded soil.

Soil quality improvement from organic farming practices is mainly associated with increase in soil organic matter and other soil properties. Study by [11] indicated that organic fertilized soil showed increase in total organic carbon, total nitrogen, available phosphorus, and exchangeable potassium. Long term application of organic fertilizer also enhances soil $\mathrm{pH}$, exchangeable calcium, exchangeable magnesium, asbuscular mycorrizhal fungi and bacterial residue [12] [13] [14] [15]. Research by [16] confirmed that application of liquid organic fertilizer decreased exchangeable $\mathrm{Al}$ and increased soil $\mathrm{pH}$ to the depth of $25 \mathrm{~cm}$ from the soil surface, even though nitrate-N was potential to move downward to deeper depth of soil profile. Application of organic fertilizer in organic farming was also reported to reasonably increase sweet corn and chili pepper production [17],[18] and organic fertilizer could substitute synthetic fertilizer for mustard [19] 
and cauliflower production [20]. Organic farming practices often lead to closed agriculture system [21], [22]. The system is referred to organic farming with high utilization of local resources and extremely limited external input to improve efficiency of resources. Such system enables us to make use of own internal resources and restricts the input of external energy [23].

Sweet corn is among organic vegetable crops commonly grown in Indonesia. Recently, growth and yield performances of sweet corn had been studied to evaluate its adaptability on organic farming environment in tropical highland. Among 7 genotypes tested in the experiment showed that genotypes of Talenta, Jambore, and Jaguar had better growth and yield performance [24]. Study by [25] indicated that most the favorable characteristics for P uptake were identified in some of corn genotypes. However, macronutrient uptake of such vegetable crop in organic farming environment has never been evaluated.

Application of solid organic fertilizer has commonly been practiced in organic farming system. However, solid organic fertilizer releases nutrient to soil slowly [26]. Application of liquid organic fertilizer is necessary to enhance fertilizing effectiveness of solid organic fertilizer. Research conducted by [27] confirmed that foliar application of N, P, and $\mathrm{K}$ fertilizer increased the nutrient uptake by maize. Another experiment, however, showed that application of tithonia enriched local liquid organic fertilizer did not affect carrot production [28]. Nonetheless, each sweet corn genotype genetically has different response to liquid organic fertilizer. The objective of this experiment was to determine nitrogen, phosphorus, and potassium uptakes by sweet corn as affected by local based liquid organic fertilizer (LOF) under closed agriculture system.

\section{MATERIALS AND METHODS}

\section{A. Site, Soil, and Amendments}

The experiment was conducted on sandy loam of Inceptisol during wet season from March to June 2015 at Closed Agriculture Production System (CAPS) Research Station located in Air Duku Village, Rejang Lebong, Bengkulu Province, Indonesia, at elevation of approximately $950 \mathrm{~m}$ above sea level. Experimental plots were established in early 2014 on long term experimental site for study of organic farming vegetable crop production and soil nutrient dynamics. The surface soil contained $2.05 \%$ organic-C, $0.19 \%$ total nitrogen $(\mathrm{N}), 5.54 \mathrm{mg} \mathrm{kg}^{-1}$ available phosphorus (P), $0.27 \mathrm{cmol} \mathrm{kg}^{-1}$ exchangeable potassium (K), $4.91 \mathrm{cmol}$ $\mathrm{kg}^{-1}$ exchangeable calcium (Ca), $0.40 \mathrm{cmol} \mathrm{kg}^{-1}$ exchangeable magnesium $(\mathrm{Mg}), \quad 1.47 \quad \mathrm{cmol} \quad \mathrm{kg}^{-1}$ exchangeable aluminum (Al), $14.32 \mathrm{cmol} \mathrm{kg}^{-1}$ Cation Exchange Capacity (CEC) and soil pH of 4.83. Soils on the site have continuously been cropped to organic vegetables since 2011. Each season, organic fertilizer at rate of $15 \mathrm{Mg}$ $\mathrm{ha}^{-1}$ had been incorporated to soil. No additional synthetic fertilizer had been applied to soil since 2011.

Solid organic fertilizer (vermicompost) was retrieved from 4x5 m square block cement. Vermicompost was produced through continuously mixed the fresh dairy cattle feces with local earthworm species for 3 months. After incubation, the compost was sieved with $2 \mathrm{~mm}$ screen.
Earthworm was, then, put back into the stock pile for next production. Vermicompost contained $25.55 \%$ organic-C, $2.15 \%$ total nitrogen, $0.24 \%$ phosphorus, and $0,55 \%$ potassium.

Liquid organic fertilizer (LOF) was manufactured in CAPS Research Station by mixing all together materials containing dairy cattle feces, dairy cattle urine, soil consisting of effective local microorganism, green leaves of Tithonia diversifolia, effective microorganisms-4 (EM-4), sugar and fresh water to a total volume of 200 liter in blue container. The mixture was incubated for 3 weeks with daily mixing up to provide sufficient aerobic environment. After incubation, the mixture was sieved using white cloth and ready for application. Liquid organic fertilizer contained $240000 \mathrm{mg} \mathrm{l}^{-1} \mathrm{~N}, 144 \mathrm{mg} \mathrm{l}^{-1} \mathrm{P}$, and $3450 \mathrm{mg} \mathrm{l}^{-1} \mathrm{~K}$.

\section{B. Experimental Design and Treatment}

Experimental design was randomized complete block with two factors of treatment. The first factor was 3 sweet corn genotypes, i.e. Talenta, Jambore, and Asian Honey and the second factor was 5 rates of LOF, i.e. $0,25,50,75$, and $100 \mathrm{mg} \mathrm{l}^{-1}$, respectively. Each treatment combination was replicated 3 times. Experimental site was separated into 3 blocks consisting of 15 plots per block. Plots were $1 \mathrm{~m}$ wide and $5 \mathrm{~m}$ long. Sweet-corn seeds were planted at a spacing of $70 \mathrm{~cm} \times 20 \mathrm{~cm}$.

\section{Field Operations}

Experimental field was plowed to $20 \mathrm{~cm}$ depth using mini tractor two weeks before planting. A week before planting, basal solid organic fertilizer (vermicompost) was hand applied to each plot at rate of $15 \mathrm{Mg} \mathrm{ha}^{-1}$. Two sweet corn seeds were grown in each planting hole in two rows. Thinning and replanting were carried out a week after planting as necessary.

Liquid organic fertilizer was applied to leaf surface using knapsack sprayer. Each plant received 25, 25, 50, 100, 150 and $250 \mathrm{ml}$ at $2,3,5,6,7$, and 8 weeks after planting, respectively. The LOF was sprayed on upper and lower leaf surface in the morning.

Sweet corn leaves were sampled at the maximum growth when tassel had emerged. Five ear leaf samples were collected from 5 randomly selected sweet corn plants in each plot. Samples were dried at $65-70{ }^{\circ} \mathrm{C}$, grinded, analyzed for $\mathrm{N}, \mathrm{P}, \mathrm{K}$ concentration in sweet corn tissues. Nitrogen, phosphorus and potassium uptakes were calculated by multiplying their concentration with shoot dry weight. Sweet corn was harvested 70 days after planting. Composite soil sample was collected in early 2014 at the depth of $0-20 \mathrm{~cm}$ using soil probe. Sample was air-dried, grinded, and sieved with 100 mesh screen and analyzed for selected soil chemical and physical properties.

\section{Statistical Analysis}

Statistical analysis was carried out using PROC GLM in Statistical Analysis System version 9.1.3 portable at $\mathrm{P}<0.05$. Sweet corn genotype treatment means were separated using Duncan's Multiple Range Test, while LOF treatment means were compared using orthogonal polynomial at probability level of 0.05 . 


\section{RESULTS AND DISCUSSION}

\section{A. Effect of Sweet Corn Genotype on Nitrogen, Phosphorus and Potassium Uptake}

Sweet corn genotype significantly influenced content and uptake of nitrogen but had no effect on those of phosphorus and potassium. Yield (weight of green ears) was also affected by sweet corn genotype (Table 1). It was generally observed that $\mathrm{N}$ and $\mathrm{P}$ content of tested sweet corn were slightly below range of their sufficient content [29], indicating that the plant might suffer from nutrient hidden hunger [30],[31], even though visual nutrient deficiency was not detected.

Table 1 also shows that Asian Honey genotype produced highest content and uptake of $\mathrm{N}$ as compared to other genotypes. Nitrogen content and uptake of Asian Honey genotype were $18.9 \%$ and $29.6 \%$ higher than that of Jambore genotype, respectively. Among genotypes investigated, Asian Honey genotype had highest content and uptake of nitrogen and phosphorus, followed by Talenta and Jambore genotypes. Potassium content and uptake had different pattern where Talenta genotype tended to be the highest followed by Asian Honey and Jambore genotype. Jambore genotype consistently provided lowest observed nutrient content and uptake. The different nutrient uptake among genotypes might be associated with genetic control variation in absorbing nutrient from soil [32],[25],[33],[34].

Highest nitrogen uptake of Asian Honey genotype, however, is not followed by the yield of sweet corn where Talenta genotype has highest yield. Yield of Talenta genotype is somehow related to uptake of potassium. Previous study by CAPS researchers reported that Talenta and Jambore genotypes were among genotypes suitable for organic farming in tropical highland [24], even though, unlike their result, Jambore genotype tested in this experiment had lowest content and uptake of N. P, K as well as its yield.

TABLE I.

CONTENT AND UPTAKE OF N, P, K AND YIELD OF SWEETCORN AS AFFECTED BY SWEET CORN GENOTYPES

\begin{tabular}{|l|c|c|c|c|c|c|c|}
\hline Genotype & \multicolumn{3}{|c|}{ Content (\%) } & \multicolumn{3}{c|}{ Uptake (mg plant $^{-1}$} & $\begin{array}{c}\text { Yield } \\
(\mathrm{Mg} \\
n^{\text {1 }}\end{array}$ \\
\cline { 2 - 7 } & $\mathrm{N}$ & $\mathrm{P}$ & $\mathrm{K}$ & $\mathrm{N}$ & $\mathrm{P}$ & $\mathrm{K}$ & $\left.\mathrm{ha}^{-1}\right)$ \\
\hline $\begin{array}{l}\text { Asian } \\
\text { Honey }\end{array}$ & $1.89 \mathrm{a}$ & 0.16 & 2.31 & $712 \mathrm{a}$ & 58 & 856 & $\begin{array}{c}16.5 \\
\mathrm{a}\end{array}$ \\
\hline Talenta & $1.84 \mathrm{a}$ & 0.15 & 2.48 & $650 \mathrm{a}$ & 48 & 884 & $\begin{array}{c}17.1 \\
\mathrm{a}\end{array}$ \\
\hline Jambore & $1.59 \mathrm{~b}$ & 0.13 & 2.42 & $549 \mathrm{~b}$ & 46 & 837 & $\begin{array}{c}12.8 \\
\mathrm{~b}\end{array}$ \\
\hline Average & 1.77 & 0.15 & 2.40 & 637 & 51 & 859 & 15.5 \\
\hline
\end{tabular}

Treatment mean followed by the same letter within column is not significantly differences at $95 \%$ confidence level.

\section{B. Effect of Liquid Organic Fertilizer on Uptake of Nitrogen, Phosphorus and Potassium}

Local based LOF linearly increased $\mathrm{N}$ content and uptake of sweet corn as shown in Figure 1. Application of LOF at rate of $100 \mathrm{mg} \mathrm{l}^{-1}$ was able to increase $\mathrm{N}$ content and uptake by $21.4 \%$ and $30.1 \%$, respectively as compared to control, even though it was generally observed that $\mathrm{N}$ content in sweet corn tissues was low [31]. This indicated that nitrogen supply was not sufficient for sweet corn growth. Local based LOF did not have an effect on content and uptake of $\mathrm{P}$ and $\mathrm{K}$ (Table 2). This might be associated with low $\mathrm{P}$ and $\mathrm{K}$ content of LOF used in this experiment. Nutrient composition of LOF is highly dependent on material components. Our local based LOF consisted of two major components, dairy cattle waste (feces and urine) and green leaves of Tithonia diversifolia, containing $144 \mathrm{mg} \mathrm{l}^{-1} \mathrm{P}$, and $3450 \mathrm{mg} \mathrm{l}^{-1} \mathrm{~K}$. Increase in nutrient composition of LOF would be reasonable way to improve effectiveness of LOF.

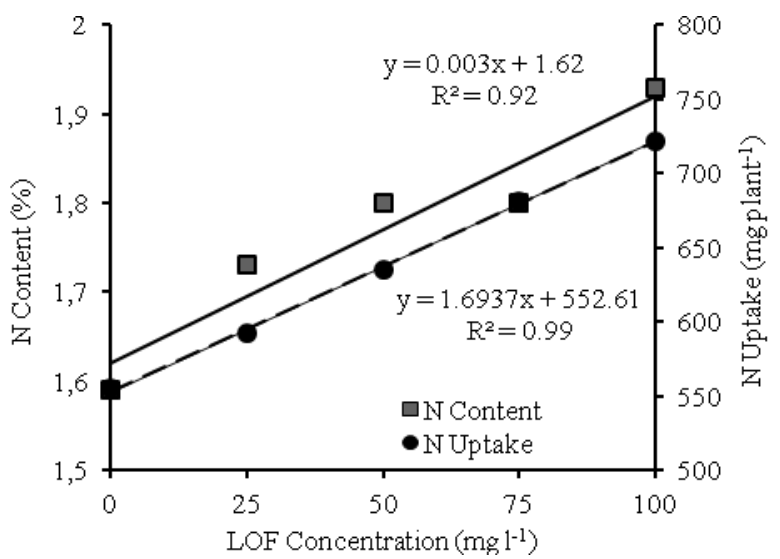

Fig 1. Nitrogen content and uptake of sweet corn as affected by liquid organic fertilizer.

Significant increase in $\mathrm{N}$ content and uptake as affected by LOF was not followed by considerable increase in yield of sweet corn (Table 2). Our finding was not similar to previous study by [35] where LOF significantly raised the yield of sweet corn. This might be attributed to the different characteristic of LOF. Low nutrient composition of our local based LOF is possible reason for unresponsiveness of sweet corn. Another reason might be due to absence of surfactant during the application of LOF, causing ineffectiveness of LOF.

TABLE II

INFLUENCE OF LIQUID ORGANIC FERTILIZER ON CONTENT AND UPTAKE OF N, P, K AND YIELD OF SWEET CORN

\begin{tabular}{|c|c|c|c|c|c|}
\hline \multirow{2}{*}{$\begin{array}{c}\text { LOF } \\
\text { Rate } \\
\left(\mathrm{mg} \mathrm{l}^{-1}\right)\end{array}$} & \multicolumn{2}{|c|}{ Content $(\%)$} & \multicolumn{2}{|c|}{ Uptake $\left(\mathrm{mg} \mathrm{plant}^{-1}\right)$} & \multirow{2}{*}{$\begin{array}{c}\text { Yield } \\
\left(\mathrm{Mg} \mathrm{ha}^{-1}\right)\end{array}$} \\
\cline { 2 - 5 } & $\mathrm{P}$ & $\mathrm{K}$ & $\mathrm{P}$ & $\mathrm{K}$ & \\
\hline 0 & 0.16 & 2.43 & 53 & 857 & 15.7 \\
\hline 25 & 0.16 & 2.51 & 57 & 877 & 16.3 \\
\hline 50 & 0.14 & 2.41 & 48 & 843 & 14.7 \\
\hline 75 & 0.12 & 2.22 & 44 & 826 & 17.8 \\
\hline 100 & 0.13 & 2.43 & 50 & 892 & 15.7 \\
\hline
\end{tabular}

Treatment mean followed by the same letter within column is not significantly differences at $95 \%$ confidence level

\section{CONCLUSIONS}

Asian Honey genotype had the highest nitrogen uptake from local liquid organic fertilizer, followed by Talenta and Jambore, however, sweet corn genotypes tested in this experiment absorbed similar amount of phosphorus and potassium. Local based liquid fertilizer significantly increased nitrogen uptake by organically grown sweet corn but not phosphorus and potassium. 


\section{ACKNOWLEDGMENT}

Sincerely appreciation goes to Directorate General of Higher Education, Ministry of Education and Culture, for financing this project through 2015 Fundamental Research Scheme. Extended thank is also handed to CAPS Research Station of Faculty of Agriculture, University of Bengkulu for providing lands for field experiments and other necessary resources.

\section{REFERENCES}

[1] R. Naravaneni, and K. Jamil, "Determination of AChE levels and genotoxic effects in farmers occupationally exposed to pesticides," Human and Experimental Toxicology, vol. 26, pp. 723-731, 2007.

[2] Z. Muktamar, S. Sujatmiko, B. Toha, M. Asteria, " Farmers are sacrificing their health for production of vegetables," in Proc. International conference on Sustainable Agriculture and Food Security: Challenges and Opportunities, 2012, pp. 141-149.

[3] P. Sengupta and R. Banerjee, "Environmental toxins: Alarming impacts of pesticides on male fertility" Human and Experimental Toxicology, vol. 33, no. 10, pp. 1017-1039, 2014.

[4] H.R. Andersen, I.M. Schmidt, P. Grandjean, T.K. Jensen, E. BudtzJorgensen, M.B. Kajaerstadt, J. Baelum, J.B. Nielsen, N.E. Skakkebaek, and K.M. Main, "Impaired reproductive development in sons of women occupationally exposed to pesticides during pregnancy," Environmental Health Perspectives, vol. 116, no. 4, pp. 566-572, 2008

[5] G. Van Maele-Fabrfy, A.C. Lantin, P. Hoet, and D. Lison, "Childhood leukaemia and parental occupational exposure to pesticides: a systematic review and meta-analysis," Cancer Causes Control, vol. 21, pp. 787-809, 2010

[6] J. Flocks, M. Kelley, J. Economos, and L. McCauley, "Female farmworkers' perceptions of pesticide exposure and pregnancy health,” J. Immigrant Minority Health vol.14, pp. 626-632, 2012.

[7] P. Barak, B.J. Babou, A.R. Krueger, L.A. Peterson, and D.A. Laird, "Effects of long-term soil acidification due to nitrogen fertilizer inputs in Wisconsin," Plant and Soil, vol. 197, no. 1, pp. 61-69. 1997.

[8] M. Ruark, L. Bundy, T. Andraski, and A. Peterson, "Fifty years of continuous corn: effects on soil fertility," in Proc. of the 2012 Wisconsin Crop Management Conference, 2012, vol. 5, pp. 127-132, 2012.

[9] M.D. Wallenstein, S. McNulty, I.J. Fernandez, J. Boggs, and W.H. Schlesinger, "Nitrogen fertilization decreases forest soil fungal and bacterial biomass in three long-term experiments," Forest Ecology and Management, vol. 222, no.1, pp. 459-468, 2006.

[10] J.D. Coolon, K.L. Jones, T.C. Todd, J.M. Blair, and M.A. Herman, :Long-term nitrogen amendment alters the diversity and assemblage of soil bacterial communities in Tallgrass Prairie," PLoS ONE, vol. 8, no. 6, pp. 1-11, 2013.

[11] S. Melero, E. Madejón, H. Engracia, Juan Francisco; and J.C. Ruiz, "Effect of implementing organic farming on chemical and biochemical properties of an irrigated loam soil," Agron. J., vol. 100, no. 1 , pp. 136-144, 2008.

[12] M.S. Clark, W.R. Horwath, C. Shennan, and K.M. Scow, "Changes in soil chemical properties resulting from organic and low-input farming practices,” Agron J. vol. 90, pp. 662-671, 1998.

[13] F. Oehl, E. Sieverding, P. Mäder, D. Dubois, K. Ineichen, T. Boller, and A. Wiemken, "Impact of long-term conventional and organic farming on the diversity of arbuscular mycorrhizal fungi," Oecologia, vol. 138, pp. 574-583, 2004.

[14] A.L. Wright, T.L. Provin, F.M. Hons, D.A. Zuberer, and R.H. White, "Compost source and rate effects on soil macronutrient availability under Saint Augustine grass and Bermuda grass turf," Compost Science \& Utilization, vol. 15, no. 1, pp.22-28, 2007.

[15] R.G. Joergensen, P. Mäder, and A.Fließbach, "Long-term effects of organic farming on fungal and bacterial residues in relation to microbial energy metabolism," Biol Fertil Soils, vol. 46, pp. 303-307, 2010.
[16] Z. Muktamar, S.Y.K. Hasibuan, D. Suryati, and N. Setyowati, "Column study of nitrate downward movement and selected soil chemical properties'change in mine spoil soil as influenced liquid organic fertilizer," J. Agricultural Technology, vol 11, no 8, pp 2017 2027. 2015.

[17] N. Setyowati, Z. Muktamar, S. Oktiasa, and D.W. Ganefianti, "Growth and yield of chili pepper under different time application of wedelia (Wedelia tribolata) and Siam weed (Cromolaena odorata) organic fertilizer," International Journal on Advanced Science Engineering Information Technology, vol 4 no 6, 2014.

[18] S. Suhri, “ Kualitas tanah dan penampilan jagung manis yang dibudidayakan secara organik pada berbagai pupuk organik padat dan cair," Thesis University of Bengkulu, 2016 ( in Indonesian, unpublished).

[19] N. Setyowati, Z. Muktamar, and I. Puspitasari, "Weed based organic fertilizer to reduce application of synthetic fertilizer in mustard (Brassica sinensis L.) J. Agricultural Technology vol 11 no 8 pp 1677-1683, 2015.

[20] M. Simarmata, L. Susianti, and N. Setyowati, "Utilization of manure and green organic compost as alternative fertilizer for cauliflower production," J. Agricultural Technology vol 12 no 2 pp 311-319, 2016.

[21] H.M. Chandrashekar, "Changing scenario of organic farming in India: An overview," Int. NGO. J. vol. 5, pp. 34-39, 2010.

[22] Z. Muktamar, S. Sudjatmiko, N. Setyowati, Fahrurrozi, and M. Chozin, "Closed agriculture production system as solution for inefficiency of agrochemical input and agricultural land deterioration," Poster session International Organic Agriculture Conference and Exhibition, 2014.

[23] K. Kudrna and M. Sindelarova, "Energetically closed agricultural systems," Journal of Central European Agriculture, vol. 3, no.4, pp. 321-332, 2002.

[24] S. Sudjadmiko, M. Chozin, Z. Muktamar, and N. Setyowati, "Yield performances of sweet corn varieties in organic system as amended with liquid organic fertilizer," International Organic Agriculture Conference and Exhibition, 2014.

[25] D.N. Ciarelli, A.M.C. Furlani, A.R. Dechen and M. Lima, "Genetic variation among maize genotypes for phosphorus uptake and phosphorus efficiency in nutrient solution," J. Plant Nutrition, vol. 21, no. 10 , pp. 2219-2229. 1998.

[26] H.D. Foth and B.G. Ellis, Soil Fertility, 2nd Ed. Lewis Publishers. New York. 1997.

[27] G. Ling and M. Silberbush, "Response of maize to foliar vs soil application of nitrogen-phosphorus-potassium fertilizer," J. Plant Nutrition, vol. 25, no. 11, pp. 2333-2342, 2002.

[28] Fahrurrozi, Z. Muktamar, N. Setyowati, S. Sudjatmiko, and M. Chozin, "Evaluation of Tithonia-enriched liquid organic fertilizer for organic carrot production," J. Agricultural Technology, vol 11, no 8, pp 1705-1712. 2015.

[29] J.B. Jones, Plant Nutrion Manual, CRC Press, New York, 1998.

[30] J.L. Havlin, J.D. Beaton, S. L. Tidale, and W.L. Nelson, Soil Fertility and Fertilizer: An Introduction to Nutrient Management, 7th ed. Pearson Printice Hall, New Jersey, 2005.

[31] E.E. Schulte and A. Kelling, " Plant Analysis: a Diagnostic Tool in National Corn Handbook," Available: http:// www.extension.purdue.edu./extmedia/nch/nch-46.html, downloaded 25 March 2015.

[32] W.G. Pollmer, D.Eberhard, D. Klein, and B.S. Dhillon, "Genetic control of nitrogen uptake and translocation in maize," Crop Sci, vol. 19, no. 1, pp. 82-86, 1978.

[33] Z. Rengel and P.M. Damon, "Crops and genotypes differ in efficiency of potassium uptake and use," Physiologia Plantarum, vol 133 , no. 4, pp. 624-636, 2008.

[34] T. Presterl, S. Groh, M. Landbeck, G. Seitz, W. Schmidt and H. H. Geiger, "Nitrogen uptake and utilization efficiency of European maize hybrids developed under conditions of low and high nitrogen input," Plant Breeding, vol. 121, no. 6, pp. 480-486, 2008.

[35] A.Rahmi and Jumiati, " Pengaruh konsentrasi dan waktu penyemprotan pupuk organik cair super ACI terhadap pertumbuhan dan hasil jagung manis," Agritrop, vol. 26, no. 3, pp. 105-109, 2007.(inIndonesian). 